\title{
Pengaruh Bimbingan Belajar terhadap Prestasi Belajar Siswa Pondok Pesantren Madrasah Aliyah Al-Utrujiyyah Kota Karang
}

\author{
Andi Thahir, Babay Hidriyanti \\ Dosen dan Mahasiswa Fakultas Tarbiyah dan Keguruan, IAIN Raden Intan Lampung \\ Diterima: Oktober 2014. Disetujui: November 2014. Dipublikasikan: Desember 2014
}

\begin{abstract}
Abstrak: Penelitian ini bertujuan untuk mengetahui dan mendeskripsikan adanya pengaruh yang ditimbulkan dari pelaksanaan bimbingan belajar terhadap prestasi belajar siswa. Untuk mencapai tujuan tersebut, penulis menggunakan metode kuantitatif dengan kuesioner dan wawancara sebagai metode utama dalam pengumpulan data. Pada proses analisis data, penelitian ini menggunakan analisis regresi sederhana dengan bimbingan belajar sebagai variabel independen dan prestasi belajar sebagai variabel dependen. Hasil dari penelitian ini adalah bimbingan belajar memiliki pengaruh terhadap peningkatan prestasi belajar siswa.
\end{abstract}

Kata Kunci : Bimbingan Kelompok, Teknik Sosiodrama, Perilaku Prososial

\section{Pendahuluan}

Pendidikan merupakan sesuatu yang memiliki tujuan yang sangat penting untuk diperoleh. Dalam skala nasional, tujuan dalam pendidikan adalah untuk mengembangkan kemampuan dan membentuk watak serta peradaban bangsa yang bermartabat dalam rangka mencerdaskan kehidupan bangsa, serta untuk mengembangkan potensi peserta didik agar menjadi manusia yang beriman dan bertakwa kepada Tuhan Yang Maha Esa, berakhlak mulia, sehat, berilmu, cakap, kreatif, mandiri, dan menjadi warga negara yang demokratis serta bertanggung jawab. Artinya bahwa tujuan pendidikan adalah membentuk orang yang mempunyai sikap atau attitude sosial yang baik, yang mampu bekerja sama dengan lingkungannya, mampu mengutamakan kepentingan umum dari pada kepentingan sendiri atau golongan.

Sedangkan fungsi diadakannya pendidikan dalam pandangan dalam Islam tidaklah jauh berbeda dengan yang ada pada tujuan pendidikan nasional di atas, dimana pendidikan tidak hanya untuk pembentukan akal atau pengembangan kompetensi para siswa saja, melainkan berfungsi juga kepada setiap bagian jiwa sehingga setiap bagian jiwa itu menjadi mampu melaksanakan tugasnya sebagaimana yang dikehendaki Allah SWT.

Dalam proses pencapaian tujuan pendidikan, siswa sebagai subyek pendidikan dapat diarahkan kepada suatu pendidikan formal dan informal. Pendidikan formal merupakan suatu jalur pendidikan yang terstruktur dan berjenjang yang terdiri atas pendidikan dasar, pendidikan menengah, dan pendidikan tinggi. Sedangkan pendidikan informal adalah jalur pendidikan di luar pendidikan formal. Dalam arti tidak dilaksanakan secara struktur dan berjenjang seperti bimbingan-bimbingan belajar, kursus, dan lain sebagainya.

Akan tetapi, dalam sebuah pendidikan dan pengajaran selalu terdapat suatu permasalahan yang berhubungan dengan proses belajar itu sendiri. Perkembangan belajar siswa yang tidak selalu berjalan lancar dan memberikan hasil yang diharapkan adalah problema dalam pendidikan. Adakalanya mereka menghadapi berbagai kesulitan atau hambatan, seperti prestasi belajar yang rendah, kurang atau tidak adanya motivasi belajar, lambatnya dalam belajar, berkebiasaan kurang baik dalam belajar, sikap yang kurang baik terhadap pelajaran, guru ataupun terhadap madrasah.

Selain adanya permasalahan dalam belajar, dalam proses pendidikan juga dapat dipengaruhi oleh adanya beberapa faktor yaitu faktor internal dan faktor eksternal. Faktor internal merupakan segala sesuatu yang berasal dari dalam diri individu yang mempengaruhi individu dalam proses pencapaian prestasi belajar di madrasah seperti: motivasi, minat, bakat 
dan intelegensi. Sedangkan faktor eksternal adalah segala sesuatu yang berasal dari luar individu baik langsung maupun tidak langsung yang dapat mempengaruhi individu dalam mencapai prestasi belajar di madrasah diantaranya meliputi lingkungan keluarga, madrasah dan masyarakat. Dimana kedua faktor tersebut haruslah berjalan berdampingan dan tidak dapat dipisahkan satu dengan lainnya, jika yang diharapkan adalah suatu prestasi yang memuaskan.

Dalam menjalani proses belajar siswa memerlukan bantuan dan bimbingan orang lain. Disadari maupun tidak dalam kenyataannya para guru di dalam semua pengajaran yang diberikan secara efektif tersirat beberapa bentuk bimbingan yang membantu seorang murid untuk mengatasi kesulitannya dalam berhitung, menunjukkan kepada murid cara-cara memperbaiki penyelesaian dan membaca kembali tugas pelajarannya, menasihati murid agar berlaku hormat dan ramah kepada orang lain adalah merupakan kegiatan atau perbuatan bimbingan. Salah satu bentuk bimbingan tersebut adalah bimbingan belajar.

Pada umumnya bimbingan yang sering dilakukan oleh sekolah-sekolah dapat berbentuk tiga macam, yaitu bimbingan pribadi dan sosial, bimbingan belajar, dan bimbingan karir. Bimbingan pribadi dan sosial diberikan dengan tujuan untuk membantu siswa memecahkan masalah yang terkait dengan masalah pribadi dan sosial. Sedangan bimbingan belajar merupakan bimbingan yang dilakukkan setiap hari di sekolah atau dalam kegiatan belajar mengajar baik pada saat ja pelajaran maupun diluar jam pelajaran.

Bimbingan dalam belajar secara khusus dapat dilakukan dalam berbagai aspek, baik dari bimbingan belajar dalam hal menulis, menghafal, memotivasi siswa, maupun bimbingan belajar dalam hal membaca. Walaupun bimbingan belajar terdapat banyak halnya, tetapi pada dasarnya bimbingan belajar tetap selalu memiliki peranan penting yang sama dalam aspek belajar siswa baik secara formal maupun informal sehingga akan dapat mendorong anak dalam mencapai prestasi belajar yang optimal. Dalam hal ini prestasi belajar merupakan hasil belajar yang dapat dicapai siswa saat dilakukan evaluasi. Menurut W.S. Winkel prestasi adalah bukti hasil belajar yang dapat dicapai siswa setelah melakukan proses belajar

Akan tetapi, suatu permasalahan muncul pada saat ini di saat sekolah merupakan hal yang wajib untuk dilakukan dan semakin berkembangnya dunia pendidikan seperti dari perkembangan teknologi dan fasilitas pendidikan justru semakin banyak siswa-siswa yang tidak memiliki motivasi untuk belajar dan menerima bimbingan-bimbingan dari para pengajarpengajarnya. Hal tersebut terbukti dengan banyaknya siswa yang suka membolos, datang terlambat, tidak mengerjakan pekerjaan rumah, dan menunjukkan sikap yang kurang wajar. Sehingga dengan hal-hal tersebut berdampak pada prestasi belajar siswa sendiri.

Hal tersebut merupakan tugas para pengajar untuk bekerja lebih ekstra, agar dapat memberikan perubahan kepada para anak didiknya menjadi lebih giat untuk belajar yang salah satunya adalah melalui bimbingan untuk belajar baik dilakukan di madrasah formal maupun informal dan bimbingan orang tua di rumah.

Beranjak dari pemikiran tersebut dan berdasarkan hasil wawancara pada saat kegiatan pra-survei dilapangan, prestasi belajar yang terdapat pada Pondok Pesantren MA AlUtrujiyyah secara umum dapat dikatakan masih minim prestasi, baik prestasi dalam bidang non-akademik maupun dalam akademik khususnya dari sisi prestasi belajarnya. Hal tersebut terbukti dengan prestasi belajar yang menurun dan nilai-nilai yang diperoleh siswa hanya setara dengan standar kurikulum pelajaran saja. Penurunan dari prestasi belajar tersebut disebakan karena banyaknya siswa yang memainkan handphone dan facebook pada jam-jam pelajaran, serta keluar-masuk kelas dengan alasan ke toilet.

Penurunan yang terdapat pada MA Al-Utrujiyyah tersebut dapat terlihat dari nilai para siswa kelas XII pada mata pelajaran al-Qur'an-Hadits, aqidah akhlak, dan fiqh Dari data yang di dapat ternyata ada 10 siswa yang nilai fiqhnya di bawah nilai KKM (kriteria kelulusan minimum) yang dengan skor 70. Sedangkan berdasarkan nilai aqidah akhlak, terdapat 21 siswa 
yang nilainya di bawah KKM, dan 38 siswa pada mata pelajaran al-Qur'an dan hadits yang juga nilainya dibawah standar KKM.

Adapun alasan peneliti untuk melakukan penelitian dengan tema tersebut adalah karena terdapatnya banyak permasalahan didalam prestasi belajar siswa yang pada akhir-akhir ini yang disebabkan oleh berbagai macam faktor dan memberikan wawasan kepada para siswa untuk agar lebih memahami akan pentingnya belajar, meningkatkan prestasi belajarnya, dan pengaruh yang diberikan melalui bimbingan belajar dalam keterampilan membaca terhadap prestasi belajarnya.

Berdasarkan uraian beberapa hal dan alasan yang telah dipaparkan diatas, maka penulis bermaksud untuk melakukan penelitian dengan judul: Pengaruh Bimbingan Belajar Terhadap Prestasi Belajar Siswa di Pondok Pesantren Madrasah Aliyah Al-Utrujiyyah. Secara harfiah, istilah bimbingan berasal dari bahasa Inggris yaitu guidance. Guidance dapat diartikan sebagai bimbingan, bantuan, pimpinan, arahan, pedoman, petunjuk. Guidance sendiri berasal dari kata "(to) guide" yang berarti menuntun, mempedomi, menjadi petunjuk jalan, mengemudikan. Adapun pembahasan dalam buku ini kata guidance dipergunakan untuk pengertian bimbingan atau bantuan.

Secara umum bimbingan dapat diartikan sebagai suatu proses pemberian bantuan kepada individu atau kelompok yang dilakukan secara berkesinambungan supaya inividu atau kelompok tersebut dapat memahami dirinya sendiri, sehingga dia sanggup mengarahkan dirinya dan dapat bertindak secara wajar, sesuai dengan tuntutan dan keadaan lingkungan sekolah, keluarga, masyarakat dan kehidupannya.

Menurut Muhammad Surya bimbingan adalah: "Suatu proses pemberian bantuan yang terus-menerus dan sistematis dari pembimbing kepada yang di bimbing agar tercapai kemandirian dalam pemahaman diri dan perwujudan diri, dalam mencapai tingkat perkembangan yang optimal dan penyesuaian diri dengan lingkungannya." Sedangkan menurut pandangan para pakar psikologi, pengertian bimbingan adalah sebagai berikut:

a. Menurut Crow dan Crow, Guidance dapat diartikan sebagai bagian yang diberikan oleh seseorang baik pria maupun wanita, yang memiliki pribadi yang baik dan pendidikan yang memadai, kepada seorang individu dari setiap usia untuk menolong dalam mengemudikan kegiatan-kegiatan hidupnya sendiri, membuat pilihannya sendiri dan memikul bebannya sendiri.

b. Menurut Stoops, bimbingan adalah suatu proses yang terus menerus dalam membantu perkembangan

c. individu untuk mencapai kemampuannya secara maksimal dalam mengarahkan manfaat yang sebesar-besarnya, baik bagi dirinya maupun masyarakat.

d. Menurut Jear dalam Book of Education bimbingan adalah suatu proses yang membantu individu melalui usahanya sendiri untuk menemukan dan mengembangkan kemampuannya agar memperoleh kebahagiaan pribadi dan kemanfaatan sosial.

Dapat disimpulkan bahwa, layanan bimbingan belajar adalah layanan bimbingan yang memungkinkan para peserta didik secara memperoleh berbagai bahan dari narasumber tertentu (terutama dari pembimbing/konselor) yang berguna untuk menunjang kehidupannya seharihari baik sebagai individu maupun sebagai pelajar, anggota keluarga dan masyarakat serta untuk pertimbangan dalam pengambilan keputusan.

\section{Fungsi dan Tujuan Bimbingan Belajar}

Dalam kelangsungan perkembangan dan kehidupan masnusia, berbagai layanan diciptakan dan diselenggarakan. Dimana layanan yang diadakan itu memberikan manfaat untuk memperlancar dan memberikan dampak positif terhadap perkembangan yang menjadi fokus dalam bidang layanan tersebut. Suatu layanan dikatakan memiliki fungsi positif jika terdapat kegunaan, manfaat, atau keuntungan yang diberikan. Suatu layanan dapat dikatakan 
tidak berfungsi jika tidak memperlihatkan kegunaan ataupun tidak memberikan fungsi atau keuntungan tertentu. Secara umum terdapat empat fungsi yang akan diperoleh dari adanya pelaksanaan layanan bimbingan belajar, diantaranya adalah:

a. Fungsi pemahaman fungsi yang diperoleh dalam hal ini artinya adalah pemahaman yang dihasilkan oleh layanan bimbingan atas permasalahan orang lain.

b. Fungsi pencegahan, Pencegahan merupakan suatu upaya mempengaruhi dengan cara yang positif dan bijaksana yang dapat menimbulkan kesulitan atau kerugian sebelum kesulitan itu benar-benar terjadi. Dalam hal ini lingkungan merupakan fokus utama yang harus dipahami, karena lingkungan yang baik akan memberikan pengaruh positif terhadap individu. Misalnya, sarana belajar yang kurang memadai, hubungan guru-murid yang kurang serasi, sarana belajar yang kurang memadai, semuanya akan menimbulkan kesulitan dan kerugian bagi siswa dalam mengembangkan diri secara optimal di sekolah.

c. Fungsi pengentasan Fungsi pengentasan adalah fungsi yang dilakukan untuk menyelesaikan permasalahan yang dihadapi oleh seseorang baik siswa, karyawan, maupun yang lainnya.

d. Fungsi pemeliharaan, Fungsi pemeliharaan adalah memelihara segala sesuatu yang baik yang ada pada diri individu, baik yang merupakan pembawaan maupun hasil-hasil perkembangan yang telah dicapai sebelumnya. Seperti intelegensi yang tinggi, bakat yang istimewa, minat yang menonjol untuk hal-hal yang psitif dan produktif, sikap dan kebiasaan yang telah terbina dalam bertindak dan bertingkah laku, cita-cita yang tinggi dan realistik, dan berbagai aspek positif lainnya dari individu perlu dipertahankan dan dipelihara.

\section{Prinsip Bimbingan Belajar}

Prinsip merupakan paduan hasil kajian teoritik dan kajian lapangan yang digunakan sebagai pedoman pelaksanaan sesuatu yang dimaksudkan. Menurut Van Hoose menjelaskan bahwa prinsip dalam layanan bimbingan belajar adalah:

a. Bimbingan didasarkan pada keyakinan bahwa dalam diri tiap anak terkandung kebaikankebaikan, mempunyai potensi diri dan pendidikan hendaknya mampu membantu anak memanfaatkan potensinya tersebut.

b. Bimbingan didasarkan pada ide bahwa setiap anak berbeda dari yang lainnya

c. Bimbingan merupakan bantuan kepada anak-anak dan pemuda dalam pertumbuhan dan perkembangan mereka agar menjadi pribadi yang sehat.

d. Bimbingan merupakan usaha membantu mereka yang memerlukan untuk mencapai apa yang menjadi idaman masyarakat dan kehidupan umumnya

e. Bimbingan adalah pelayanan, yang dilaksanakan oleh tenaga ahli dengan latihan khusus, dan untuk melaksanakan pelayanan bimbingan diperlukan minat pribadai khusus pula.

\section{Faktor yang Mempengaruhi Bimbingan Belajar}

Secara global, faktor-faktor yang mempengaruhi belajar siswa dapat kita bedakan menjadi tiga macam, yakni:

a. Faktor internal (faktor dari dalam diri siswa), yakni keadaan/kondisi jasmani dan rohani siswa. Faktor yang berasal dari dalam diri siswa sendiri meliputi dua aspek, yakni:

1) Aspek fisiologis yakni kondisi umum jasmani yang menandai tingkat kebugaran organorgan tubuh dan sendi-sendinya, yang dapat mempengaruhi semangat dan intensitas siswa dalam mengikuti pelajaran. Kondisi organ tubuh yang lemah, apabila disertai pusing kepala berat misalnya, maka dapat menurunkan kualitas ranah cipta (kognitif) sehingga materi yang dipelajarinya tidak berbekas. Untuk dapat mempertahankan jasmani agar tetap bugar, maka siswa sangat dianjurkan mengkonsumsi makanan dan minuman yang bergizi. Selain itu siswa juga dianjurkan memilih pola istirahat dan olahraga ringan yang sedapat mungkin terjadwal secara tetap dan berkesinambungan. Hal ini penting karena kesalahan 
pola makan-minum dan istirahat akan menimbulkan reaksi yang negatif dan merugikan semangat mental siswa itu sendiri

2) Aspek Psikologis yang meliputi:

a) Inteligensi siswa yang pada umumnya dapat diartikan sebagai kemampuan psikofisik untuk mereaksi rangsangan atau penyesuaian diri dengan lingkungan dengan cara yang tepat. Jadi inteligensi sebenarnya bukan persoalan kualitas otak saja, melainkan juga kualitas organ-organ tubuh lainnya.

b) Sikap siswa adalah gejala internal yang berdimensi afektif berupa kecenderungan untuk mereaksi atau merespon dengan cara yang relatif tetap terhadap obyek orang, barang dan sebagainya, baik secara positif maupun negatif.

c) Bakat siswa secara umum adalah kemampuan potensial yang dimiliki seseorang untuk mencapai keberhasilan pada masa yang akan datang. Dengan demikian sebetulnya setiap orang pasti memiliki bakat dalam arti berpotensi untuk mencapai prestasi sampai ketingkat tertentu sesuai dengan kapasitas masing-masing. Jadi secara global bakat itu mirip dengan inteligensi, karena itu seorang anak yang berinteligensi sangat cerdas (superior) atau cerdas luar biasa (very superior) disebut juga sebagai talented child, yakni anak berbakat.

d) Minat siswa secara sederhana adalah kecenderungan dan kegairahan yang tinggi atau keinginan yang besar terhadap sesuatu. Minat tidak termasuk istilah populer dalam psikologi karena ketergantungannya yang banyak pada faktor-faktor internal lainnya seperti pemusatan perhatian, keingintahuan, motivasi dan kebutuhan.

e) Motivasi siswa ialah keadaan internal organisme baik manusia ataupun hewan yang mendorongnya untuk berbuat sesuatu. Dalam hal ini motivasi berarti pemasok daya (energizer) untuk bertingkah laku secara terarah.

3) Faktor eksternal (faktor dari luar siswa), yakni kondisi lingkungan disekitar siswa. Ada dua aspek, yaitu:

a) Lingkungan sosial sekolah seperti para guru, para staf administrasi, dan teman-teman sekelas dapat mempengaruhi semangat belajar siswa disekolah. Para guru yang selalu menunjukkan sikap dan perilaku yang simpatik dan memperlihatkan suri teladan yang baik dan rajin khususnya dalam hal belajar, misalnya rajin membaca dan berdiskusi, dapat menjadi daya dorong yang positif bagi kegiatan belajar siswa. Yang termasuk lingkungan sosial siswa adalah masyarakat dan tetangga juga teman-teman sepermainan disekitar perkampungan siswa tersebut. Kondisi masyarakat dilingkungan kumuh yang serba kekurangan dan anak-anak penganggur, akan sangat mempengaruhi aktivitas belajar siswa, paling tidak siswa tersebut akan menemukan kesulitan ketika memerlukan teman belajar atau berdiskusi dan meminjam alat-alat belajar tertentu yang kebetulan belum dimilikinya. Lingkungan sosial yang paling banyak mempengaruhi kegiatan belajar ialah orang tua dan keluarga siswa itu sendiri. Sifat-sifat orang tua, praktik pengelolaan keluarga, ketegangan keluarga, dan demografi keluarga (letak rumah), semuanya dapat memberi dampak baik ataupun buruk terhadap kegiatan belajar dan hasil yang dicapai oleh siswa.

b) Lingkungan nonsosial yang termasuk dalam faktor lingkungan nonsosial ialah gedung sekolah dan letaknya, rumah tempat tinggal keluarga siswa dan letaknya, alat-alat belajar, keadaan cuaca, dan waktu belajar yang digunakan siswa.

c) Faktor pendekatan belajar (approach to learning), yakni jenis upaya belajar siswa yang meliputi strategi dan metode yang digunakan siswa untuk melakukan kegiatan mempelajari materi-materi pelajaran. Dapat dipahami sebagai segala cara atau strategi yang digunakan siswa dalam menunjang keefektifan dan efisiensi proses mempelajari materi tertentu. Strategi dalam hal ini berarti seperangkat langkah operasional yang direkayasa sedemikian rupa untuk memecahkan masalah atau mencapai tujuan belajar tertentu. 


\section{Bidang Layanan Bimbingan Belajar}

Dalam bidang bimbingan belajar membantu siswa untuk mengembangkan diri, sikap, dan kebiasaan belajar yang baik dan menguasai pengetahuan dan keterampilan merupkan hal yang paling utama. Bimbingan belajar atau akademik ialah bimbingan dalam hal menemukan cara belajar yang tepat, memilih program studi yang sesuai, dan mengatasi kesulitan yang timbul berkaitan dengan tuntutan -tuntutan di suatu institusi pendidikan. Kekeliruan dalam memilih program studi di tingkat pendidikan menengah dan pendidikan tinggi dapat membawa akibat fatal bagi kehidupan seseorang. Cara-cara belajar yang salah juga dapat berakibat pada penguasaan program studi yang kurang baik.

Sebelum melakukan bimbingan, hendaknya guru atau pembimbing perlu mengetahui secara pasti masalah yang dihadapi oleh siswa dalam bidang studinya. Hal tersebut karena disamping banyaknya siswa yang berhasil secara baik dalam belajar, dijumpai pula adanya siswa yang gagal, seperti hasil nilai ujian yang kurang baik atau tidak naik kelas. Secara umum siswa yang demikian dipandang sebagai siswa yang mengalami masalah belajar. Akan tetapi secara lebih luas, masalah belajar memiliki bentuk yang beragam, yang pada umumnya dapat digolongkan atas beberapa kelompok, yaitu:

a. Keterlambatan akademik, yaitu keadaan siswa yang diperkirakan memiliki intelegensi yang cukup tinggi, tetapi tidak dapat memanfaatkan secara optimal

b. Kecepatan dalam belajar, yaitu keadaan siswa yang memiliki bakat akademik yang cukup tinggi atau memiliki IQ yang tinggi, tetai masih memerlukan tugas-tugas khusus untuk memenuhi kebutuhan dan kemampuan yang amat tinggi

c. Sangat lambat dalam belajar, yaitu keadaan siswa yang memiliki bakat akademik yang kurang memadai dan perlu dipertimbanagkan untuk mendapat pndidikan atau pengajaran khusus

d. Kurangnya motivasi dalam belajar, yaitu keadaan siswa yang kurang bersemangat dalam belajar dan seolah-olah tampak bosan malas.

e. Bersikap dan berkebiasaan buruk dalam belajar, yaitu kondisi siswa yang kegiatan belajar sehari-harinya antagonistik dengan yang seharusnya, seperti menunda-nunda tugas, membenci guru, tidak ingin bertannya untuk hal-hal yang tidak diketahui, dan sebagainya.

\section{A. Konsep Keterampilan Membaca}

\section{Pengertian Membaca}

Membaca adalah satu keterampilan dalam ilmu bahasa Indonesia. Dengan membaca, siswa akan lebih mudah dalam mencerna dan memperoleh informasi. Melalui kegiatan membaca, siswa dapat memahami pesan dan makna dari suatu bacaan, di samping itu dapat meningkatkan prestasi belajar siswa di sekolah secara lebih optimal.

Secara harfiah membaca berasal dari kata baca yang artinya melihat serta memahami isi dari apa yang tertulis (dengan melisankan atau hanya dalam hati), selain itu baca atau membaca juga diartikan sebagai mengeja atau melafalkan apa yg tertulis, mengucapkan, meramalkan dan menduga. Dengan membaca seseorang dapat memetik serta memahami arti yang terkandung di dalam bahan tulis.

Membaca merupakan suatu proses untuk mencerna, memahami, dan mendapatkan informasi menterjemahkan simbol-simbol bunyi (huruf) kedalam kata-kata lisan sehingga memperoleh pemahaman atau pengetahuan atas sesuatu yang dibaca tersebut.

\section{Tujuan pada Keterampilan Membaca}

Kegiatan membaca yang dilakukan oleh seseorang tentu memiliki tujuan tertentu. Namun pada dasarnya membaca memiliki dua tujuan, yaitu tujuan umum dan tujuan khusus. Tujuan umum membaca adalah untuk mencari dan mendapatkan informasi dari 
sumber yang dibaca. Sedangkan secara khusus Tarigan mengemukakan bahwa membaca memiliki beberapa tujuan lain, yaitu:

a. Membaca untuk menemukan atau mengetahui penemuan-penemuan yang telah dilakukan oleh para penemu. Membaca seperti ini disebut membaca untuk memperoleh perincian atau fakta (reading for details or facts).

b. Membaca untuk mengetahui mengapa hal tersebut merupakan topik yang baik atau menarik. Membaca seperti ini disebut membaca untuk memperoleh ide-ide utama (reading for mains ideas).

c. Membaca untuk mengetahui apa yang terjadi pada setiap bagian cerita. Membaca seperti ini disebut membaca untuk mengetahui urutan atau susunan (reading for sequence or organization).

d. Membaca untuk mengetahui serta menemukan mengapa para tokoh merasakan. Membaca seperti ini disebut membaca untuk menyimpulkan, membaca inferensi (reading for inferensi).

e. Membaca untuk mengetahui dan menemukan apa-apa yang tidak bisa atau tidak wajar mengenai seorang tokoh. Membaca seperti ini disebut membaca untuk mengelompokkan (reading for classify).

f. Membaca untuk mencari atau menemukan apakah tokoh berhasil atau hidup dengan ukuran-ukuran tertentu. Membaca seperti ini disebut membaca untuk menilai (reading tu evaluate).

g. Membaca untuk menemukan bagaimana caranya tokoh berubah. Membaca seperti ini disebut membaca untuk membandingkan atau mempertentangkan (reading for compare or contrasts)

\section{Teknik yang Diperlukan untuk Menumbuhkan Kemahiran Membaca}

Mahir dalam membaca merupakan hal yang dapat dilakukan oleh semua orang. Dalam upaya untuk meningkatkan minat dan kemampuan membaca siswa, sebaiknya pembelajaran keterampilan membaca harus dilakukan dalam suasana yang menyenangkan bagi siswa, dan yang lebih menentukan lagi adalah terciptanya interaksi guru dan siswa yang bersifat personal dan santun sehingga tercipta Susana pembelajaran yang kondusif dan menyenangkan antara guru dan siswa. Ada beberapa hal yang harus dikuasai bila ingin memiliki kemahiran dalam membaca. Brown menyebutkannya kedalam beberapa hal penting, yaitu:

a. mampu membedakan pola-pola tulisan dan ejaan bahasa

b. mampu menerima bagian-bagian bahasa dalam memori jangka pendek

c. kecepatan memproses tulisan yang dibaca untuk mencocokkan dengan tujuan

d. mengenali inti kata dan menginterpretasi pola susunan kata untuk menemukan makna teks yang dibaca

e. mengenali kelompok gramatikal kata, sistem, pola, tata cara dan bentuk elepsisi yang digunakan

f. mengenali bahwa bentuk tertentu dapat diekspresikan dalam bentuk gramatikal yang berbeda

g. mengenali alat-alat kohesif yang digunakan dan perannya dalam menandai hubungan antar klausa

h. mengenali bentuk retorika wacana dan signifikansinya untuk interpretasi

i. mengenali fungsi komunikatif teks tulisan menurut bentuk dan maksudnya,

j. menduga link dan hubungan antarperistiwa dan ide, mengambil keputusan sebab akibat, dan menditeksi setiap hubungan sebagai main ide, ide pendukung, informasi

a. baru, pemberian informasi generalisasi dan contoh, membedakan makna literal dan makna di balik teks 
b. menditeksi referensi khusus secara kultural dan menginterpretasinya dalam suatu konteks yang sesuai dengan kultur skemata

c. mengembangkan dan menggunakan

d. strategi membaca, mendeteksi pemarkah wacana, menebak makna kata dari konte dan mengaktifkan skemata untuk menginterprtasi teks.

\section{B. Prestasi Belajar}

\section{Pengertian Prestasi Belajar}

Menurut Winkel prestasi adalah bukti keberhasilan usaha yang dapat dicapai. Dari pendapat tersebut dapat dipahami bahwa prestasi adalah suatu hasil usaha yang diperoleh seseorang atas usaha yang dilakukan. Dalam bahasa Inggris sendiri sebenarnya ada sebuah kata atau istilah lain yang lebih menggambarkan "prestasi" dalam pengertian Indonesia atau sebagimana digunakan dalam bahsa Indinesia yaitu kata "achievement". Tetapi karena kata itu berasal dari dari kata "to achieve" yang berarti mencapai", kita lebih sering menerjemahkanya menjadi "pencapaian" atau "apa yang dicapai.

Berprestasi adalah suatu dorongan yang ada pada setiap manusia untuk mencapai hasil kegiatannya atau hasil kerjanya secara maksimal. Secara naluri setiap orang mempunyai kebutuhan untuk mengerjakan atau melakukan kegiatannya lebih baik dari sebelumnya, dan bila mungkin untuk lebih baik dari orang lain. Namun dalam realitanya, untuk berprestasi atau mencapai hasil kegiatannya lebih baik dari sebelumnya atau lebih baik dari orang lain itu idak mudah, banyak kendalanya, justru kendala yang dihadapi dalam mencapai prestasi inilah yang mendorongnya untuk berusaha mengatasinya serta memelihara semangat kerja yang tinggi dan bersaing mengungguli orang lain. Oleh sebab itu maka motif berprestasi adalah sebagai pendorong untuk sukses dalam situasi kompetisi yang didasarkan pada ukuran "keunggulan" disbanding dengan standar ataupun orang lain.

Prestasi akademik adalah hasil yang diperoleh berupa pengetahuan, keterampilan, nilai (values) dan sikap yang menetap sehingga mengakibatkan perubahan dalam diri individu sebagai hasil dari aktivitas dalam belajar, sehingga dapat dipakai sebagai ukuran untuk mengetahui sejauh mana siswa menguasai bahan pelajaran yang diajarkan dan dipelajarinya.

\section{Indikator Prestasi Belajar}

Pada prinsipnya menggunakan hasil belajar idealnya meliputi segenap ranah psikologis yang berubah sebagai akibat pengalaman dan proses belajar. Hasil yang diperoleh melalui proses belajar ini dinyatakan dengan nilai-nilai (scores), dimana dengan nilai-nilai tersebut dapat dilihat apakah prestasi akademik siswa tersebut tinggi atau rendah. Namun demikian, pengungkapan perubahan tingkah laku seluruh ranah itu, khususnya ranah rasa murid sangat sulit. Hal ini disebabkan perubahan hasil belajar itu ada yang bersifat intangible (tak dapat diraba). Oleh karena itu yang dapat dilakukan dalam hal ini adalah hanya mengambil cuplikan perubaha tingkah laku yang dianggap penting dan diharapkan dapat mencerminkan perubahan yang terjadi sebagai hasil belajar siswa, baik yang berdimensi cipta, rasa maupun yang berdimensi karsa.

\section{Faktor yang Memperngaruuhi Prestasi Belajar}

Prestasi belajar bukanlah sesuatu yang berdiri sendiri, tetapi merupakan hasil berbagai faktor yang melatar belakanginya. Dengan demikian, untuk memahami tentang prestasi belajar perlu di dalami faktor-faktor yang mempengaruhinya,

a. Faktor eksternal

Faktor ekstenal yang dapat mempengaruhi prestasi belajar peserta didik dapat digolongkan kedalam faktor sosial dan non sosial. Faktor sosial menyangkut hubungan antar 
manusia yang terjadi dalam berbagai berbagai situasi sosial. Dalam faktor ini termasuk lingkungan keluarga, sekolah, teman dan masyarakat pada umumnya. Sedangkan faktor non sosial adalah faktorfaktor lingkungan yang bukan sosial seperti lingkungan alam dan fisik, misalnya keadaan rumah, ruang belajar, fasilitas belajar, bukubuku sumber, dan sebagainya.

b. Faktor internal

Sekalipun banyak pengaruh atau rangsangan dari faktor eksternal yang mendorong individu belajar, keberhasilan belajar itu akan ditentukan oleh faktor diri (internal) beserta usaha yang dilakukannya. Brata mengklasifikasikan faktor internal mencakup:

- faktor-faktor fisiologis, yang menyangkut keadaan jasmani atau fisik individu, yang dapat dibedakan menjadi dua macam yaitu keadaan jasmani pada umumnya dan keadaan fungsifungsi jasmani tertentu terutama panca indra.

- faktor-faktor psikologis yang berasal dari dalam diri seperti intelegensi, minat, sikap, dan motivasi

Intelegensi merupakan salah satu faktor yang berpengaruh terhadap tinggi rendahnya prestasi. Intelegensi merupakan dasar potensial sebagai pencapaian hasil belajar, artinya hasil belajar yang dicapai akan bergantung pada tingkat inteligensi, dan hasil belajar yang dicapai tidak akan melebihi tingkat intelegensinya.

Minat (interest), yaitu kecenderungan atau kegairahan yang tinggi atau keinginan yang besar terhadap sesuatu. Oleh kerena itu, minat dapat mempengaruhi pencapaian hasil belajar. Umpamanya peserta didik yang menaruh minat besar terhadap kesenian akan memusatkan perhatiannya lebih banyak dari pada yang lain.

Sikap adalah gejala internal yang berdimensi afektif, berupa kecenderungan untuk mereaksi atau merespon dengan cara yang relatif tetap teradap objek orang, barang, dan sebagainya, baik secara positif maupun negatif.

\section{Penilaian Terhadap Prestasi Belajar}

Prestasi belajar merupakan suatu bentuk pengakuan terhadap hasil belajar. Suatu hasil belajar dapat dikategorikan memiliki prestasi jika hasil belajar sesuai dengan tujuan pembelajaran. Menurut Gagne dalam bukuNana Sudjana, menjelaskan bahwa hasil belajar dibagi menjadi lima macam, yaitu invormasi verbal, ketrampilan intelektual, strategi kognitif, sikap dan ketrampilan motoris. Konsep Gagne pada dasarnya sesuai dengan konsep taksonomi Bloom, yaitu kognitif, afektif, dan psikomotorik.

\section{Metode Penelitian}

Jenis penelitian ini adalah penelitian lapangan (Field Research), yaitu penelitian yang bertujuan untuk mempelajari secara intensif tentang latar belakang keadaan sekarang dan interaksi lingkungan suatu unit sosial baik individu, kelompok, lembaga, atau masyarakat. Penelitian lapangan dilakukan dengan menggali data yang bersumber dari lokasi atau lapangan penelitian yang berkenaan dengan bimbingan yang dilakukan atau yang diterima oleh siswa dalam mempengaruhi prestasi belajar siswa. Selain itu, peneliti ini juga menggunakan penelitian kepustakaan (Library Research). Penelitian kepustakaan adalah penelitian yang dilaksanakan dengan menggunakan literatur (kepustakaan), baik berupa buku, catatan, maupun laporan hasil penelitian terdahulu.

\section{Hasil dan Pembahasan}

Penelitian ini menggunakan bimbingan kelompok dengan teknik sosiodrama. kegiatan bimbingan kelompok dilaksanakan di dalam kelas kepada peserta didik kelas X SMA Negeri 10 Bandar Lampung yang berjumlah 200 peserta didik dalam penelitian ini diketahui kriteria 
tertinggi dengan persentase $8 \%$, namun masih terdapat peserta didik yang dikriteria sedang dengan persentase $84,5 \%$ dan kriteria rendah dengan persentase $7,5 \%$. Ketika individu mendapatkan pembelajaran yang baik tentang norma sosial maka akan prososial, sebaliknya individu yang tidak mendapatkan pembelajaran yang baik tentang sebuah norma sosial maka akan antisosial. Konflik-konflik yang ada di masyarakat akan menguatkan sikap individu terhadap suatu perilaku dan niatnya untuk memberikan pertolongan ataupun tidak memberikan pertolongan karena, pada dasarnya setiap individu dalam berinteraksi atau berhubungan sosial individulah yang menyesuaikan terhadap lingkungan sekitar bukan lingkungan tersebutlah yang menyesuaikan kepada individu itu sendiri. Berdasarkan analisis data pretest dan posttest menunjukkan bahwa adanya peningkatan perilaku prososial pada peserta didik SMA Negeri 10 Bandar Lampung setelah diberikan perlakuan melalui bimbingan kelompok teknik sosiodrama, diketahui bahwa hasil posttest lebih tinggi yaitu 62,2 sedangkan hasil pretest yaitu 36,9. Hal ini menunjukkan bahwa perilaku prososial peserta didik meningkat sebesar 25,3. Sehingga Ho ditolak dan Ha diterima. Untuk mengetahui apakah Bimbingan Kelompok dengan Teknik Sosiodrama dapat meningkatkan perilaku prososial peserta didik sebelum dan setelah diberikan layanan bimbingan kelompok teknik sosiodrama dengan menggunkan rumus analisis data t-test, dengan taraf signifikan (a) 0,5. Adapun hipotetis statistiknya adalah sebagai berikut; $\mathrm{H} 0 \quad: \mu 1=\mu 2$

Ha $: \mu 1 \neq \mu 2$

Berdasarkan hasil uji paired sampel t-test bimbingan kelompok dengan teknik sosiodrama untuk meningkatkan perilaku prososial peserta didik, perhitungan perilaku prososial peserta didik dilakukan dengan menggunakan SPSS for windows reliase 16, didapat hasil sebagai berikut diketahui bahwa t adalah 10.782 mean adalah 2533.33 , $95 \%$ confidence interval of the difference, lower $=30.37273$ dan upper $=20.29394$.

Kemudian t hitung dibandingkan dengan t tabel $\mathrm{dk}=14$, dengan ketentuan t hitung lebih besar dari t tabel $(10.782>1.761)$, dengan demikian perilaku prososial peserta didik kelas $\mathrm{X}$ SMA Negeri 10 Bandar Lampung mengalami perubahan setelah diberikan layanan bimbingan kelompok dengan teknik sosiodrama. Sehingga, dapat ditarik kesimpulan bahwa bimbingan kelompok dengan teknik sosiodrama berpengaruh dalam mengatasi perilaku prososial peserta didik di SMA 10 Negeri Bandar Lampung.

Meningkatkan perilaku prososial peserta didik melalui bimbingan kelompok dengan memanfaatkan teknik sosiodrama dilakukan beberpa tahap bimbingan dengan lima kali peretemuan. Ada empat tahap dalam layanan bimbingan kelompok yang dilakukan oleh peneliti. Hal tersebut sesuai dengan pendapat Romlah dalam Dian Novianti Sitompul yang menjelaskan bahwa bimbingan kelompok memiliki empat tahapan yaitu: tahap pembentukan, tahap peralihan, tahap kegiatan dan tahap pengakhiran.

Berdasarkan hasil analisis menunjukkan bahwa terdapat perbedaan pada setiap sub indikator. Menurut Mussen indikator perilaku prososial seperti; menolong orang lain, berbagi, berempati, bekerjasama dan bertindak jujur. Setelah mendapatkan perlakuan dengan memanfaatkan teknik sosiodrama, terlihat adanya perbedaan pada setiap sub indikator sebagai berikut;

a. Perilaku menolong orang lain

Pada indikator perilaku menolong orang lain meningkat dari $2,75 \%$ menjadi $4,83 \%$, hal ini terlihat pada saat penyebaran angket perilaku prososial sebelum dan sesudah perlakuan. Seiring dengan peningkatannya terlihat peserta didik mampu memberikan bantuan tanpa diminta, peka terhadap orang yang

membutuhkan serta memberikan pertolongan tanpa melihat siapa yang ditolong. Artinya, bahwa peserta didik mampu memberikan bantuan kepada peserta didik yang sedang membutuhkan pertolongan sekalipun peserta didik tersebut bukanlah orang yang masuk kedalam kelompok bermainnya atupun yang memiliki kedekatan khusus. 


\section{b. Perilaku empati}

Pada indikator empati meningkat dari $2,57 \%$ menjadi 5,3\%. Perilaku empati adalah perilaku yang ditunjukkan berupa kemampuan orang lain untuk dapat merasakan apa yang dirasakan oleh orang lain, peserta didik mulai menunjukkan rasa yang sama dengan apa yang dirasakan hal tersebut sesuai dengan pendapat Mussen yang menyatakan bahwa orang-orang yang tinggi pada orientasi empati akan menunjukkan lebih simpati dan menaruh perhatian pada orang lain yang sedang dalam kesusahan, kesedihan, dan sukarela bertindak prososial. Artinya, bahwa peserta didik yang memiliki perilaku empati yang baik maka akan cenderung untuk berperilaku prososial.

c. Perilaku bertindak jujur

Pada indikator perilaku kejujuran meningkat dari 2,93\% menjadi 4,22\%. Peserta didik menunjukkan perilaku yang tidak bersifat kecurangan seperti peserta didik lebih percaya diri dalam mengerjakan pekerjaan rumah yang ditugaskan oleh guru sesuai dengan kemampuan yang ia miliki, peserta didik mampu mengatakan apa adanya, serta mampu jujur dengan diri sendirinya seperti menyadari segala kekurangan yang dimilikinya.

d. Perilaku berbagi

Pada indikator perilaku berbagi meningkat dari $2,7 \%$ menjadi $4,7 \%$. Hal tersebut dapat terlihat ketika peserta didik ikhlas memberikan apa yang dimilikinya dan memiliki kesedian untuk berbagi dengan orang lain dalam susana suka maupun duka seperti, memberikan dukungan kepada peserta didik lainnya yang sedang mengalami kesulitan.

e. Perilaku bekerjasama

Pada indikator bekerjasama meningkat dari $2,75 \%$ menjadi $4,73 \%$. Hal ini dapat terlihat ketika peserta didik mampu bertanggung jawab bersama-sama dalam menyelesaikan tugas yang diberikan oleh guru serta peserta didik saling berkontribusi baik tenaga mapun pikiran dengan orang lain seperti ikut andil dalam memberikan masukan ataupun gagasan serta menerima masukan pada saat diskusi sedang berlangsung tanpa menyela walaupun berbeda dengan pendapat yang ia kemungkakan.

Setelah melaksanakan kegiatan bimbingan kelompok dengan teknik sosiodrama yang dilakukan dalam lima kali pertemuan. Peneliti merasa senang ketika perilaku prososial peserta didik meningkat karena terlihat dari tiap indikator yang mencakup perilaku prososial. Tercapainya tujuan penelitian terlihat dari perubahan perilaku dan pengetahuan yang didapat oleh masing-masing peserta didik. Hal ini terlihat dari deskripsi perilaku prososial dengan teknik sosiodrama dari tiap pertemuan.

\section{Simpulan}

Setelah melakukan pembahasan terhadap data-data yang diperoleh dalam penelitian, maka pada bab penutup tersebut penulis akan memberikan kesimpulan dan saran agar selanjutnya Pondok Pesantren MA Al-Utrujiyyah menjadi lebih baik dalam hal meningkatkan prestasi belajar kepada para siswanya.

Adapun kesimpulan yang didapat adalah berdasarkan data yang telah di analisis oleh penulis, maka dapat disimpulkan bahwa variabel bimbingan belajar yang diteliti pada penelitian ini memiliki pengaruh terhadap peningkatan prestasi belajar pada siswa. Hal tersebut terbukti dengan adanya hasil pengujian dari analisis Uji T, dimana pada analisis tersebut nilai thitung > ttabel sebesar 7,973 > 2,074. Hal ini menjelaskan bahwa dalam hipotesis yang diterima pada uji $\mathrm{T}$ adalah Ha. Dimana arti dari Ha adalah bimbingan belajar memiliki pengaruh yang signifikan terhadap prestasi belajar siswa di MA Al-Utrujiyyah.

\section{Daftar Pustaka}

Ahmadi, Abu, dan Ahmad Rohani, Bimbingan dan Konseling, Rineka Cipta, Jakarta, 1991. Arikunto, Suharsimi, Prosedur Penelitian, PT Rineka Cipta, Jakarta, 1990. 
Azwar, Saifuddin, Pengantar Psikologi Inteligensi, Pustaka Pelajar, Yogyakarta, 2006.

Hana, Attia Mahmud, Bimbingan Pendidikan dan Pekerjaan, Bulan Bintang, Jakarta, 1978. Hapsari, Sri, Bimbingan dan Konseling, Grasindo, Jakarta, 2005.

Hasan, Iqbal, Analisis Data Penelitian Dengan Statistik, Bumi Aksara, jakarta, 2008.

Hasan, M. Ali dan Mukti Ali, Rapita Selekta Pendidikan Agama Islam, Pedoman Ilmu Jaya, Yogyakarta, 2003.

Hikmawati, Fenti, Bimbingan Konseling, Raja Grafindo Persada, Jakarta, 2010.

KBBI, Pusat Bahasa DEPDIKNAS, Jakarta, 2008.

Kuncoro, Mudrajad, Metode Riset Untuk Bisnis dan Ekonomi, Erlangga, Jakarta, 2003.

Margono, Metodologi Penelitian Pendidikan, Rineka Cipt, Jakarta, 2004.

Mulyasa, Implementasi Kurikulum 2004 Panduan Pembelajaran KBK, PT Remaja

Rosdakarya, Bandung, 2004.

Notoatmodjo, Soekidjo, Pengembangan Sumber Daya Manusia, Rineka Cipta, Jakarta, 2009.

Priyatno, Duwi, Paham Analisis Statistik Data Dengan SPSS, Mediakom, Yogyakarta, 2010. Purwanto, Erwan Agus, dan Dyah Ratih Sulistyastuti, Metode Penelitian Kuantitatif: Untuk

Adminstrasi Publik dan Masalah-masalah Sosial, Gaya Media, Yogyakarta, 2007.

Rahim, Farida, Pengajaran Membaca di Sekolah Dasar, Bumi Aksara, Jakarta, 2005.

Soeratno dan Lincolin Arsyad, Metodologi Penelitian: Untuk Ekonomi dan Bisnis, Edisi

Revisi, UPP STIM YKPN, Yogyakarta, 2008.

Subagyo, Joko, Metode Penelitian dalam Teori dan Praktik, Rineka Cipta, Jakarta, 2011.

Sudarmanto, Gunawan, Analisis Regresi Linier Ganda Dengan SPSS, Graha Ilmu, Yogyakarta, 2005.

Sudjana, Nana, Penilaian Hasil Proses Belajar Mengajar, Remaja Rosdakarya, Bandung, 2005.

Sukmadinata, Nana Syaodih, Landasan Psikologis Proses: Proses Pendidikan, Remaja Rosda Karya, Bandung, 2007.

Sugiono, Metode Penelitian Bisnis, Alvabeta, Bandung, 2009.

Sukardi, Dewa Ketut, Pengantar Pelaksanaan Program: Bimbingn Belajar dan Konseling di Sekolah, Rineka Cipta, Jakarta, 2002.

Suryabrata, Sumadi, Metodologi Penelitian, PT Raja Grafindo Persada, Jakarta, 1998.

Syah, Muhibbin, Psikologi Belajar, PT Raja Grafindo Persada, Jakarta, 2009.

Tarigan, Henry Guntur, Membaca sebagai Suatu Keterampilan Berbahasa, Angkasa, Bandung, 2008.

Tika, Moh. Pabundu, Metodologi Riset Bisnis, Bumi Aksara, Jakarta, 2006.

Tim Pengembang Ilmu Pendidikan, Ilmu dan Aplikasi Pendidikan, Grasindo, Jakarta, 2007. Undang-undang Republik Indonesia Nomor 20 Tahun 2003 Tentang Sistem Pendidikan Nasional

Walgito, Bimo, Bimbingan dan Konseling, Andi Offset, Yogyakarta, 2010

Widodo, Chomsin S, Jasmadi, Panduan Menyusun Bahan Ajar Berbasis Kompetensi, PT Elex Media Komputindo, Jakarta, 2008.

Winkel, Psikologi Pengajaran, Grasindo, Jakarta, 1991.

Winkel, James I, Pengajaran Berhasil, Alih Bahasa Simanjuntak, UI Pers, Jakarta, 1982. 